\title{
Estabilidade antigênica e patogenia de amostras do vírus rábico após sucessivas inoculações em camundongos*
}

\author{
HELENA BEATRIZ DE CARVALHO RUTHNER BATISTA
}

Paulo Michel Roehe (Orientador - UFRGS)

Banca: Amauri Simonetti (UFRGS), Celso Bittencourt dos Anjos (SEVS), Rudi Weiblen (UFSM).

A raiva é uma zoonose causada pelo vírus da raiva (VR), um membro do gênero Lyssavirus da família Rhabdoviridae. Apesar do VR, ser considerado antigenicamente estável, amostras com variações antigênicas têm sido detectadas. Na busca de identificar possíveis variantes circulantes no Brasil, um dos objetivos do presente estudo foi identificar as características antigênicas de amostras de vírus rábico circulantes nas regiões Centro-Oeste e Norte do Brasil. Para tanto, amostras do VR coletadas naquelas regiões, isoladas de diferentes hospedeiros, tiveram seu perfil antigênico avaliado por imunofluorescência indireta frente a um painel de anticorpos monoclonais preparados contra antígenos de lissavírus. Foram identificados três perfís antigenicamente distintos: um característico de amostras de origem de cães domésticos, outro de amostras de morcegos hematófagos e outro de amostras de morcegos não hematófagos. O segundo objetivo deste estudo consistiu em avaliar a estabilidade antigênica e a patogenia de amostras com tais perfís antigênicos distintos. Para atingir este objetivo, três amostras de VR com diferentes perfís antigênicos foram submetidas a vinte inoculações sucessivas em camundongos. Á medida em que as passagens eram realizadas, o perfil antigênico das mesmas era monitorado. Os resultados obtidos revelaram que todas as amostras mantiveram-se relativamente estáveis e todas as amostras ao longo as 20 inoculações mantiveram altamente patogênicas. Duas delas (a amostra com perfil antigênico de cães e a amostra com perfil antigênico de morcegos hematófagos) mantiveram-se antigenicamente estáveis ao longo de todas as 20 inoculações. Por outro lado a amostra com perfil antigênico usualmente detectado em morcegos não hematófagos apresentou uma modificação antigênica após a sétima passagem sucessiva. Isto pode indicar diferenças no grau de adaptação do vírus à espécie hospedeira natural. Sumarizando os resultados desses estudos, conclui-se que as variantes do VR circulantes nas regiões Norte e Centro-Oeste do Brasil possuem características antigênicas comuns a amostras cujos hospedeiros naturais são cães domésticos, morcegos hematófagos e morcegos não hematófagos. As variantes detectadas apresentam um elevado grau de estabilidade antigênica; a variante cujo hospedeiro natural são morcegos não hematófagos parece menos estável antigenicamente. Essa menor estabilidade antigênica poderia ter relação com o grau de adaptação à espécie hospedeira natural, hipótese que será examinada mais profundamente em estudos futuros.

Descritores: vírus da raiva, caracterização antigênica, variantes.

Apresentada: 15 janeiro 2007

"Dissertação de Mestrado n. 333 (Especialidade: Virologia). 75f. Programa de Pós - graduação em Ciências Veterinárias [www.ufrgs.br/ppgcv], Faculdade de Veterinária, Universidade Federal do Rio Grande do Sul (UFRGS), Porto Alegre, RS/Brasil. CORRESPONDÊNCIA: H.B.C.R. Batista [hruthner@yahoo.com.br]. 


\title{
Antigenic stability and patogeny on rabies virus strains after consecutive inoculations in mice ${ }^{* *}$
}

\author{
HELENA BEATRIZ DE CARVALHO RUTHNER BATISTA
}

\author{
Paulo Michel Roehe (Adviser - UfRGS)
}

Committee: Amauri Simonetti (UFRGS), Celso Bittencourt dos Anjos (SEVS), Rudi Weiblen (UFSM).

\begin{abstract}
Rabies is caused by rabies virus (RV), a member of the genus Lyssavirus within the family Rhabdoviridae. Despite the acknowledged antigenic stability of RV, variants have been identified. In search for RV variants circulating in Brazil, one of the objectives of the present study was to identify the antigenic profile of RV isolates from different natural host species in North and Central West regions of Brazil. The isolates had its antigenic profiles determined by indirect immunofluorescence with a panel of monoclonal antibodies prepared to lyssavirus antigens. Three distinct antigenic profiles were detected: one characteristic of isolates from domestic dogs, another in isolates from vampire bats and another in non haematophagous bats. A second aim of the present study was to evaluate the degree of antigenic stability and patogeny of RV isolates with such distinct antigenic profiles. For that, three RV isolates were submitted to twenty successive inoculations in mice and periodically monitored in search for antigenic alterations. The results obtained revealed that in fact the three isolates were quite stable antigenically and all strains after 20 consecutive inoculations maintained higly patogenics. Two of the viruses (dog and vampire bat profiles) remained antigenically stable throughout the twenty successive passages in mice. On the other hand, the isolate with an antigenic profile commonly found in non haematophagous bat viruses revealed an antigenic modification after the seventh passage in mice. This could be indicative of differences in the degree of adaptation of the isolate to its natural host species. Summarizing the results of theses studies, it was concluded that RV variants circulating in the Centre-West and North regions of Brazil display antigenic profiles common to those usually detected in isolates whose natural hosts are domestic dogs, haematophagous and non hematophagous bats. Such variants display a relatively high degree of antigenic stability; however, the variant whose natural hosts are non haematophagous bats seem less antigenically stable. Such lesser degree of antigenic stability might be related to the degree of adaptation of the virus to its natural host species. Such hypothesis shall be examined more deeply in future studies.
\end{abstract}

Key words: rabies virus, antigenic characterization, variants. 